Paper presented to Australasian Housing Researchers Conference, University of Adelaide, June 2006.

Title: The Roll of the State? Changing housing policy imagination and practice in four advanced economies.

Jago Dodson, Urban Research Program, Griffith University

j.dodson@griffith.edu.au 
Title: The Roll of the State? Changing housing policy imagination and practice in four advanced economies.

\begin{abstract}
:
Recent scholarship has argued that the 'rollback' of the state under neo-liberalism has been accompanied and followed in many jurisdictions by a corresponding 'rollout' of new forms state activity and practice. Housing scholars in Europe have recently sought to assess the 'rollback' hypothesis in housing contexts. Many have observed that there is only limited evidence for the withdrawal of the state in housing. Some argue that there has been a 'restyling' of state responsibilities in housing, but that such changes do not equate simply to a withdrawal. This paper engages with the 'rollback' hypothesis in housing by asking how the state has been imagined in housing assistance policy in four case study jurisdictions and what does this tell us about the contemporary role of the state in housing. The case studies include Australia, New Zealand, the UK and the Netherlands. The paper argues that the practices of housing assistance policy in each jurisdiction have undergone some change, particularly towards the adoption of a 'rational consumer' subjectivity as the model for housing assistance clients. Overall however, the contemporary state retains a major role in constituting and constructing the perceived objects, subjects and practices of housing assistance and that any assessment of diminished state activity in housing must therefore take account of this persistence. From this perspective, while state housing policies may have altered the specific practices of the state in addressing housing problems, the discursive role of the state in perceiving housing problems, imagining policy relationships and articulating housing policy solutions remains strong and arguably barely diminished.
\end{abstract}

\title{
Introduction
}

Provision of housing assistance to individuals and households has long been an activity of government, particularly since the late-19th Century when the acute misery of the urban poor began to be revealed by social reformers in Europe and the United States (Harloe 1995). In most Western nations the state intervened directly to supply housing during the early and mid 20th Century via large bureaucratic institutions. This provision expanded rapidly after 1945 in many jurisdictions. The costs of major public housing programmes continued to increase in the late-1960s and critics began to argue that such policies were no longer fiscally or socially sustainable or necessary. Absolute shortages of housing were diminishing and with economic growth slowing in the late-1960s, the cost of the welfare state was increasingly viewed as an excessive drain on public finances. The perceived inadequacies of the modern architectural principles deployed in many public housing schemes were viewed by many commentators as demonstrating the inadequacy of state intervention in housing provision.

Since the 1970s, governments have pursued two broad responses to the management of social housing. The first is to introduce new management methods into social housing including new institutional forms and targeting of resources. A second response has been for governments increasingly to rely on housing allowances to provide demand assistance for housing to low-income households. Together these two general policies 
have reshaped housing across in many countries, of which four will be considered in detail in this paper.

The paper argues that while direct state delivery and regulation of social housing may have been withdrawn in some jurisdictions, in many cases the state retains a dominant capacity to imagine and define not only housing reality, but also institute this reality through the institutional and governmental relationships of social housing. The paper directly addresses the theme of the Australian Housing Researchers Conference 'unleashing the housing imagination' by examining the changing comprehension of the state and state activity in housing policy and in government more generally.

\section{The roll of the state}

Housing policy does not exist in a vacuum. The changes to social housing programs that have occurred since the 1970s must be placed in a broader social and economic context. Prominent among social and economic shifts since the 1970s has been neoliberalism. Neoliberalism (or neo-classical economics, the 'new right', economic rationalism) encompasses a suite of philosophical and economic theories that have become propminent in public discourse since the late 1960s (Hayek 1948; Nozick 1974), and which derive much of their intellectual inspiration from the earlier interest among latenineteenth century classical economists and liberal economists (Smith 1970; Mill 1972) with the beneficial operation of markets.

Neoliberal thought typically holds as its most basic tenet that the most efficient means for achieving an efficient distribution of social goods and services is through the operation of markets. This belief in the allocative superiority of markets is accompanied by a sceptical assessment of government's abilities to achieve social or collective goals (Bourdieu 1998), such that governments should refrain from providing public infrastructure and services (Graham and Marvin 2001), in favour of private agencies (Friedman and Friedman 1981).

Self (2000) describes three related elements of neoliberal discourse. Economically, markets are percieved as the most rational means of resource allocation; socially, markets are conceived as constituting a robust set of individual rights, responsibilities and opportunities; and, politically neoliberalism asserts that the state should defer to the market all functions except those which are most fundamental to the polity, such as law, defence, policing.

The advent of neoliberalism as a basis for government policy has been noted by numerous scholars, many of whom report a 'rolling back' of the state (Kelsey 1993) as governments shift allocation decisions to markets, the status of the individual as the basic social unit is emphasised and provision of goods and services is shifted to the private sector (Peck and Tickell 2002). Rollback implies that the state has 'withdrawn' from the social and economic spheres. This metaphor implies an absence of the state or a governmental void.

More recently, scholars have argued that new forms of state activity are being 'rolled out' under neoliberalism. Peck and Tickell (2002) have argued that earlier perceptions of neoliberalism as a totalizing political force are now giving way to more nuanced and sensitive assessments of the changing character of the contemporary neoliberal state. As some aspects of governmental activity have been withdrawn new types of state activity are being extended. Peck and Tickell (2002) also argue that geography is strongly influencing how neoliberalism is being pursued at the regional, national and global scale. Rather than involving a unidirectional process of governmental change, neoliberalism is being incorporated and transformed by local and national practices. Historical 
trajectories, existing social practices and cultural formations can all potentially influence how neoliberalism is adopted or pursued.

The particular governmental practices that emerge from this confluence of new doxa and geography do not necessarily result in a 'roll back' of the state; such new forms may also comprise a 'roll out'. In many countries neoliberal housing policies have brought new managerial and institutional forms that rely on market models for comprehending welfare and the status of individual recipients of housing assistance (Woods 2000). Doherty (2004) has argued that the 'roll back' thesis is not universally applicable in housing policy. In many European nations the application of neoliberal principles to housing has been often weak and uneven (Blanc 2004; De Decker 2004). Yet elsewhere neoliberalism has been a strong force in housing policy. New Zealand's market rents experiment is a clear example although the general and obvious shift towards greater use of demand subsidies (Oxley 1987; Kemp 1997; Ditch et al. 2001; Hulse 2002) indicates greater governmental deployment of market and individual subjectivities on the part of assistance recipients. An understanding of developments in contemporary state policy necessarily requires a recognition of these processes. But this also implies the need for attentiveness to the governmental characteristics of neoliberal practices.

\section{Governmentality and housing}

The notion of 'governmentality' proposed by Foucault (1979) has been productively deployed by a number of scholars to comprehend the advent of neoliberalism and the social forms that this doctrine has generated. Governmentality theorists argue that modern societies have undergone a transition from direct forms of state disciplinary control to indirect methods. Direct hierarchical state regulation has been supplanted by more dispersed methods of government in which the power of the state is diffused through various regulatory and advisory agencies and practices involving both the public and private sectors. Deleuze (1988, p.75) interpreted governmentality to mean that "there is no State, only state control". This effect can be observed in the management of metropolitan regions. Such territories may now be governed by an array of neoliberal institutional forms and relationships in which no single agency retains superordinate hierarchical methods of economic or social control but among which government remains able to be expressed (McGuirk 2003).

Scholars of neoliberal governmentality also argue that this political form is associated with a specific liberal subjectivity on the part of individuals (Burchell 1993; Hindess 1993; Dean 1995; Rose 1996). The production of the 'liberal individual' through modern state social and economic practices is viewed as a critical 'technology' that underpins the capacity of the state to avoid direct methods of control and organisation (Foucault 1979). Rather than deploying direct methods of social control, neoliberal governmentality aspires to produce a self-regulating liberal subjectivity in which the individual takes on the responsibility for their own conduct. The housing scholarship of King (2003) which advocates the adoption of an individual libertarian morality in the government of housing exemplifies this neoliberal governmentality.

Housing policy scholars have to date been reticent in applying governmentality theory to the understanding of housing policy processes. Only a few explicitly housing orientated engagements with governmentality have been put forward in recent years and these have been quite spatially specific engagements (Flint 2002; McDermott 2004). Flint (2002; 2004) for example, has examined how tenant behavioural control has become increasingly central to the function of social housing agencies in the UK and that this suggests a strong governmental but weak state mode of regulation. There have been few attempts to comprehend the governmentality of housing assistance a broader macro 
policy level. There is clearly scope for a governmentality approach to illuminate the role of the state in housing policy change under neoliberalism.

\section{The state of The State}

An understanding of the role of the state under neoliberalism is critical to comprehending governmentality in housing policy. Governmentality theory assumes that state control has become less hierarchical and centralised and more diffuse and dispersed. Deleuze has described this shift as a transition from disciplinary societies to 'societies of control'. Irrespective of the specific form of government that has emerged, observers of neoliberalism and theorists of governmentality have tended to overlook a critical feature of contemporary state practice. This characteristic is the retention by the state of a very strong, indeed dominant, capacity to determine not only the mode of government that is to be deployed but the discursive basis for that deployment. Indeed the state remains the primary site for the articulation of governmental discourse, irrespective of its other activities. The production, articulation and implementation of housing policy, for example, continues to be the domain of the state, irrespective of whether the policy specifies a social or a market mode of action. This ideological or discursive capacity is implicitly recognised in most recent Marxist theorisations of the 'role of the state' under capitalism, such as that of Poulantzas (1973) or Jessop (1982) including the function of 'state apparatuses' (Althusser 1971), but is largely ignored by both governmentality theorists and more conventional political perspectives.

In most jurisdictional instances in housing policy, while 'roll back' of the state may be superficially apparent it is the state that establishes whether such roll back should occur and determines the specific characteristics of that rollback. The existing state comprises part of the political and economic context that Peck and Tickell (2002) have observed affecting how neoliberalism is practiced in different geographical jurisdictions. The state continues to define the reality and dimensions of its own practices even if those practices may change. Neoliberalism may therefore be comprehended as a doctrine of the state, not opposed to it (1979).

This feature of contemporary state practice deserves further investigation and discussion because it has important implications for our assessments of the import of neoliberalism and the perceived opposition of this doctrine to the state. If neoliberalism is 'of the state' then it may be influenced by influencing the state. I describe the problem of accounting for the production of a definable governable reality by the state as a problem of 'statementality'. This term reflects the observation made by Bourdieu and Wacquant regarding the symbolic power of language. Symbolic power for Bourdieu and Wacquant is the "power to constitute the given by stating it, to act upon the world by acting upon the representation of the world". Statementality is the ongoing capacity of the state to constitute its own condition and to define the parameters of its own actions.

Recognising the ongoing symbolic power of the state to constitute social reality mitigates the anxieties that many feel regarding the 'withdrawal', 'withering' or 'roll back' of the state. While state practices may have changed, the power of the state to define the reality of its own existence endures. The state remains the focal point of discursive and ideological production even if it has altered the specific practices through which it governs the reality of the world. The claims of state withdrawal therefore deserve serious scrutiny lest we uncritically adopt such perceptions. Topalev (1979, p.446) reminded us that "[a] minimum of epistemological vigilance requires us to question the nature of what the state baptises as housing reality". We must be mindful of this injunction when the state advises of its own re-imagined neoliberal reality, in housing or in other policy spheres. 
The remainder of this paper examines four examples of recent policy change to ask three questions: how has housing policy been re-imagined?; how does this re-imagining of housing reflect neoliberal governmentality?; and what is the role of the state in these processes of housing policy change?. The four case studies are those of the United Kingdom, the Netherlands, Australia and New Zealand. These cases provide a useful comparative range in terms of the historical tenure balance between social and private housing provision, and in terms of the extent of encroachment of neoliberal doxa (Bourdieu and Wacquant 2001) into the objects, subjects and relations of housing assistance. Given the broad theoretical ambition and the four-nation empirical scope, the analysis engages with housing policy imagination and change at the level of the overall policy framework, rather than delving in detail to examine specific instances of policy change.

\section{The state of housing in the United Kingdom}

During the immediate post-WWII period the UK invested substantially in public housing operated by local municipalities, producing a Council housing tenure and stock that rose from a negligible level in the 1910s to 31 per cent by 1980 (Ball 1983, p.2). UK housing policy was organised around the constitution of housing as a 'merit good' and the state imagined its role as ensuring a supply of housing adequate to accommodate all citizens (Whitehead 1993). Under conditions of emerging neoliberalism in the late 1970s and early 1980s, the privatisation of Council began through the Right-to-Buy scheme promoted by the Thatcher Conservative government. The governmental conception of housing changed at this time from an object that was best provided by the state to a good that was best provided by the individual. Under privatisation in the 1980s and 1990s the the tenure share of Council housing declined to 22.4 per cent by 1990 (Whitehead 1993, p.118) and 14 per cent by 2002 (Office of National Statistics 2004, p.36). While Right-toBuy lost momentum in the 1990s 1.6 million households had purchased dwellings through the scheme by 2000 (DETR 2000). The Conservative government also began a process of 'demunicipalisation' that transferred large numbers of Council dwellings to non-profit Registered Social Landlords or Housing Associations. This stock transfer program had the governmental objective of improving efficiency and responsiveness of social housing provision while reducing the scale of local housing monopolies. Between 1988, when the program began, to 2001, 600,000 dwellings were transferred to RSLs in England alone.

Policies such as Right-to-Buy and the demunicipalisation program may appear as the 'withdrawal' of the state. Yet the state drove the policies and was the determining force in the imagination of reduced state housing activity. Privatisation occurred at the behest of and was directly facilitated by the state. The social power of the state has remained strong.

\section{Re-constituting UK housing assistance}

A Labour government was elected in 1997 and articulated a new neoliberal discourse of housing assistance. The neoliberal constitution of housing under Labour is partly continuous with that of the preceding Conservative regime. The private market remains a dominant object in Labour's housing imagination. Private home ownership is now strongly supported and Labour expresses neoliberal anxieties about direct state control of housing supply. This new state imagination of housing policy retains support for 
collective and social housing provision even if this provision is dispersed among many new quasi-independent social housing entities.

The green paper Quality and Choice: A Decent Home For All (DETR 2000) states in detail the government's imagined order of housing across the three major sectors in the UK - private rental, home-ownership and social rental - as well as articulating the constitution of the role of demand subsidies within this discursive arrangement. The green paper is too extensive to consider in substantial detail here. However it suffices to identify the essential elements and how government is constituted through this regime.

In the green paper public tenants have been transformed from passive recipients of state beneficence to rational choice-oriented housing consumers who select among a range of alternative sources of housing that which most closely matches their selfidentified needs and purchasing capacity (King 2003; Marsh 2004). This deployment of the 'rational consumer' of housing signifies a neoliberal governmentality in operation. Rather than government determining the need experienced by a given individual or household and the type of housing that is appropriate to them, the individual is required to determine and exercise 'choice' in selecting housing that meets their own needs among various sectors of housing provision. The state imagines the transformative power of the rational consumer subjectivity bringing utopian results:

Applicants for social housing who are more involved in decisions about their new homes are more likely to have a longer term commitment to the locality. This will promote more sustainable communities at village, town and city level. It will increase personal well-being, and help to reduce anti-social behaviour, crime, stress and educational under-achievement. (DETR 2000)

The critical practical imperative for government is thus to ensure the presence of a range of quasi non-governmental housing providers that are sufficiently administratively efficient to ensure the clear expression of consumer choices.

The Green Paper also proposed a series of administrative reconfigurations for social housing, including inward financial investment, diversification of housing provision agencies, price-oriented rent-setting procedures, greater managerial efficiency and provision of greater dwelling selection to tenants. Of these changes two are particularly pertinent - diversification of social housing providers and greater dwelling choice. Diversification of provision has largely been achieved through the transfer of Local Council housing to Registered Social Landlords (RSLs) or Housing Associations. Tenant choice in housing provider was to be achieved by increasing tenant involvement in the management of RSLs and allowing RSLs to target particular tenant groups whose needs they could then be 'more responsive and sensitive to' (DETR 2000, p.60).

A further feature of the green paper reforms has been the attempt to institute greater national uniformity in the pricing of social housing. A lack of coherence (Marsh 2004, p.190) in rental pricing systems for social housing is viewed as generating inefficiencies and inadequacies in the social sector with implications for rational consumers. Walker and Marsh (2003, p.2024) suggest that UK social rents 'give tenants little incentive to optimise their housing consumption'. The Housing Green Paper addresses these perceived problems through a new rent setting formula that simulates market rent-setting while constraining actual rents in relation to local households' capacities to pay for housing (Marsh 2004).

Some have viewed the broad shifts signalled by Quality and Choice: A decent home for all as marking a transition from a 'command' model to a 'social market' (Kemeny 1995) model of housing governance (Stephens et al. 2003). In contrast, a governmentality perspective suggests that the 'social market' is as much an object that is constituted by government as is the conventional bureaucratic 'command' method. What remains critical, however, to understanding the post-2000 UK housing reforms is their 
imagination of new policy objects - choice, responsibility - and new subjectivities on the part of tenants and housing agencies. The autonomous consumer is a product of neoliberal government and attempts to constitute the social housing tenants as 'autonomous' consumers are directly dependent on the regulatory capacity of government. Statementality and the 'conduct of conduct' remain integral to the entire rearrangement of housing in the UK under the Quality and Choice policy.

This section has focused in limited detail on the UK context, but this basic problem of understanding government not as something that is extended or withdrawn but as social force that persists despite changes to the material practices by which is it constituted, remains common to housing policy across many jurisdictions. Similar effects are apparent in the systems of the Netherlands.

\section{Housing policy change in the Netherlands}

The Netherlands has a long history of state involvement in housing provision and assistance dating from the early-20th Century. By the mid-1990s the social sector comprised 40 per cent of total Netherlands housing stock (Boelhower 2002). There is little social stigma associated with social housing (Priemus 1996) partly because a large proportion of the population is housed by the social sector. Landlord autonomy was historically limited and rents were required to follow a trendhuurbeleid or 'rent trend' price policy set by the state (Hoekstra 2003).

Consumer demand and government policy stimulated a shift to private homeownership during the 1980s and 1990s (Dieleman 1999). Government premiekoopregelingen or 'premium house purchase regulations' were critical to this change as they granted premiums to home purchasers if certain conditions regarding the price of the dwelling and household incomes were satisfied. This gave the government indirect influence over the production and price setting of newly built owner-occupied dwellings (Hoekstra 2003). While the market was involved, it was highly shaped by government policy settings.

A much stronger emphasis on the use of market processes in the provision of housing occurred after 1989 (Boelhower 2002) with housing percieved less as a 'merit good' and more as a market object. The 1993 Decree on the Subsidised Rented Sector (Dieleman 1999) changed the operation of the housing association sector by requiring social landlords to retire debt while also instituting five 'accountability themes', namely: provision of housing for those unable to sufficiently obtain suitable housing for themselves; monitoring quality of newly constructed and existing dwellings; involving tenants in housing management; sound financial practices; and promoting a high quality of life within residential neighbourhoods and estates (Dieleman 1999). In 1995 supply subsidies were abolished and demand-oriented housing allowances became the primary direct instrument of housing assistance for modest- and low-income households in the Netherlands (Priemus and Kemp 2004).

The 1993-1995 re-imagining of housing assistance in the Netherlands was followed in 2000 by the new government memorandum on housing titled What People Want Where People Live ( MHSPE 2001). This document has set the subsequent agenda for housing policy in the Netherlands during the early part of this decade. In What People Want Where People Live the state imagines housing policy as a relationship between three housing objects (MHSPE 2001, p.5). The first major object is choice. The purpose of housing policy in the Netherlands is to expand the magnitude of this object possessed by the primary subject of housing policy - the individual - who is constituted as a consumer expressing personal desires and preferences for housing. Choice for consumers is positioned in this discursive arrangement to two other objects - the social collective and 
the market. The social collective is however constituted as being of greater importance than individual choice such that restrictions are placed on the individual's expression of personal preference. The market object is constituted as capable of providing housing but requires 'hands on' governmental control to protect weaker consumers.

The new apprehension of the individual consumer as the primary subject of housing policy is clearly and deliberately enunciated in the Netherlands housing policy. Thus the policy perceives "an ongoing process of individualisation and emancipation in the housing market" in which people "want more say" in their housing (MHSPE 2001, p.5). The state seeks to achieve this further empowerment of the housing policy subject by "placing the individual in the limelight" (MHSPE 2001, p.5) where they are required to "assume more responsibility" for their housing (MHSPE 2001, p.7). The government also imagines freedom of choice being impeded by various obstacles which the state must act to remove by: ensuring the financial capacity of the individual; fostering the social skills of the individual; ensuring the housing supply; promoting the participation of the individual; and constructing an appropriate institutional framework. Freedom is produced by state intervention, not state absence.

The changes to the Netherlands housing assistance arrangements during the present decade are yet to be fully realised. However it is possible to reflect on the way that the shifts observed in the Netherlands involve a change in the mode of governmental constitution and practices of housing policy, and what the implications are for understanding the role of the state.

As has been the case in the UK the Netherlands housing policy has shifted markedly to comprehend the market as a much more capable housing object than was the case until relatively recently. The subject of housing has also been transformed from being a member of a broader social collective to being a consuming autonomous socialindividual exercising choice within a housing market that offers housing matched with the individual's preferences. The social character of housing has changed from being a good that all members of society could relatively easily access to being differentiated on the basis of tenure and affordability within the context of market processes. While most individuals or households will be constituted as owner-occupiers, the remainder, less socially capable groups will be directed to the social rented sector.

Critical to this transformation of housing policy in the Netherlands, as in the UK however, is the enduring capacity of the state as the legitimate site of enunciation of the governmental order of housing. It is the state that has enunciated this changed order of housing policy and articulated the altered subjects and objects of housing policy. Similarly, it is the state that will undertake the process of governing the empirical social practices of housing policy to effect and enact this new discursive order. Despite the identification of the market as the new force in the housing system the state remains the overall dominant discursive force. The state retains control through its deployment of an order of housing that it determines.

\section{Housing assistance in New Zealand}

The New Zealand case demonstrates perhaps the greatest extent of the neoliberal governmental imagination of housing policy as the 'reality' of housing. The New Zealand example assists to demonstrate the extent to which neoliberal governmentality comprehends housing, but that this necessarily relies on a strong state capacity to undertake this process of imagining. By the early 1980s, New Zealand operated a mixed housing assistance policy, similar to that operating in comparable jurisdictions such as Australia or Canada. The majority of rental housing assistance was provided through a 'bricks and mortar' supply subsidy administered by the government Housing Corporation of New Zealand (HCNZ). In the early 1980s, the HCNZ held almost 58,000 rental 
houses (Housing Corporation of New Zealand 1984) with rents were calculated at 25 per cent of tenant income.

Following the election of a Labour government in 1984, New Zealand's public policies began to emphasize the role of markets as allocation mechanisms for public resources (Kelsey 1995; Boston et al. 1996). The Housing Corporation of New Zealand became one of the targets of deregulation and rationalization, due both to its large bureaucratic size and substantial mortgage and rental housing assets. The Corporation avoided privatization in the 1980s but, like many other state sector agencies, was required to implement quasi-commercial managerial changes (Housing Corporation of $\mathrm{New}$ Zealand 1989).

After the 1990 election a newly elected National Party government accelerated and expanded the Labour's program of neoliberal public sector restructuring including privatization of many state assets. The government also instituted a series of cuts to welfare policies, including a universal 10 per cent reduction in welfare benefits in 1991.

Housing assistance was radically restructured (Luxton 1991). The supply subsidy provided via income-related social rents was replaced with a universal demand subsidy the Accommodation Supplement - while the Housing Corporation was required to operate as a commercial enterprise, charging market rents to low-income tenants. The changes were phased in between 1993 and 1995. While the policy was abandoned in 2001 , it is of interest in understanding neoliberal governmentality in practice.

These changes to New Zealand's housing policy were informed by highly dogmatic a neoliberal governmental imagination of the proper conduct of economic and social agents (see New Zealand Treasury 1987). This governmentality determined that the only way in which housing could be provided efficiently was for the full market price of supplying the housing to be made apparent. Furthermore, it was considered appropriate that the state should not distort the housing tenure preferences of low-income renters by providing different subsidy levels to state tenants compared to demand subsidized private rental tenants in similar circumstances (Luxton 1991), irrespective of the greater support needs of some groups. And because the delivery of a supply subsidy did not expose the Housing Corporation to market competition, this lack of market exposure was perceived as providing insufficient incentive to the agency to supply housing efficiently and effectively. Commercial discipline was the neoliberal prescription for this perceived inadequacy.

\section{The simulated market}

The problem of governmentality in the operation of the market rents model and the accommodation supplement demand subsidy of the state in housing is demonstrated by two features of the New Zealand regime. These features also signify the active ongoing presence, rather than withdrawal of the state in housing under neoliberalism. The first relates to the role of state officials in setting the payment rates for the Accommodation Supplement. In the allowance formula a number of variables control the payment provided to a given housing assistance recipient. Setting the values for these variables requires a process of determination by state officials (Jensen 1994). Thus the New Zealand model required sufficient knowledge on the part of the state to comprehend the operation of the housing market, the rent burden experienced by low-income households, and the apposite level of demand subsidy necessary to ameliorate affordability difficulties. The attempt to inculcate a market rationality among housing agencies and the recipients of housing assistance is therefore entirely dependent for its operation on the capacities of the state to determine the settings by which that system will operate. 
This observation demonstrates the irony of the New Zealand expression of neoliberalism in housing. The establishment of a market system is dependent on a strong 'statementality' for it's constitution and operation. At most New Zealand's market rents housing policy created a 'simulated market' in which the government retained directive control the major instruments of the policy through either the Accommodation Supplement or Housing New Zealand and modulated these at its discretion.

The political aspects of the New Zealand policy also deserve some consideration. The government faced substantial and ongoing political pressure to amend the market rents housing policy. From the time of initial implementation to the eventual reversal of the policy in 2001 the government actively and frequently responded to public pressure by amending the practices of Housing New Zealand to accommodate considerations other than market rationality. Behind the apparent market relationships in New Zealand's housing policy was the ongoing capacity of the state to determine housing reality and to manipulate the housing sector. The freedom of the rational consumer in New Zealand remained contingently determined by the calculations and assessments of state officials. If the Accommodation Supplement settings were too generous tenants would be 'inefficient' in their housing consumption but if the variables were set too low tenants will suffer hardship and constrained choice (Jensen 1994). Ironically therefore, the possibility for apparent 'state withdrawal' from housing depends on the perceptual capacities of the state. It is also curious that a doctrine of government in which the state is viewed as incapable of allocating resources should retain the centrality of the state in the possibility of its operation.

From a governmentality theoretical perspective, the introduction of the neoliberal model of housing assistance can thus be comprehended not as an exercise in the state relinquishing control over the individual, but a shifting, as Foucault (1979) and Deleuze have suggested, from direct and hierarchical to modulated, variable and diffuse governmental control. The state remains closely involved but the mode of intervention has been transformed from direct administration to distanciated calibration and adjustment of assistance mechanisms and settings. The mechanisms of assistance and their invocation of freedom and efficiency as mobilizing concepts merely re-constitute the form of state control but do not diminish it.

Neoliberal governmentality was partly reconfigured in New Zealand after 2001. Housing supply assistance is now provided on the basis of state assessed social need rather than through commercial or market mechanisms. However for those not determined to be sufficiently needy to receive a state controlled dwelling demand support via a private rental market housing allowance remains. In expenditure terms, the housing allowance continues as the dominant mode of delivering housing assistance.

\section{Housing Assistance in Australia}

The Australian social housing experience also reflects the emergence of neoliberal governmental arrangements and an associated shift from supply dominated housing assistance to a predominantly demand-subsidised mode. However the particular political arrangements operating in Australia have influenced the process of policy change as the impacts of superordinate policy shifts at the Federal level are diffracted through divergent policy and administrative arrangements among the States. The Australian case is also marked by an uneven and much less explicit programmatic application of neoliberal constructs to housing assistance than has applied elsewhere. Australian housing assistance demonstrates the encroachment of a neoliberal governmentality on housing 
assistance policy but also highlights how such governmentality is transfigured by local contexts.

Australia's main public housing assistance program has operated since 1945, when the first Commonwealth-State Housing Agreement (CSHA) was created. Within Australia's federal governmental structure, periodic CSHAs have provided for Commonwealth financial assistance to the States, which supply rental housing assistance to individuals and households via State Housing Authorities (SHAs).

Because each Australian State and Territory operates its own SHA, specific programs and policies differ between each, complicating detailed comparison of policy shifts. Discussion here is restricted to the experience of the state of Victoria, which is often viewed as an exemplar of the application of neo-liberalism to state-level public policy (Alford and O'Neill 1994). Necessarily however any Australian account must also examine the emergence and distribution of neoliberal thought at the Federal sphere (Pusey 1991).

By the early-1980s, Australia had approximately 218,400 units of public housing (Burke et al. 1984, p.103) with 45,241 in Victoria (Ministry of Housing 1984a, p.14). The 1980s saw marked increases in Federal contributions to public rental housing, with CSHA public rental funds increasing annually from $\$ 347$ million in 1982/1983 to almost $\$ 700$ million in 1987/1988 while national stock levels increased from approximately 236,000 in 1982 to approximately 320,000 in 1988 (Persson 1989, p.115). The fiscal cost of Australia's public housing program had since the 1970s recieved attention from economic conservatives with some observers arguing in favour of neoliberal approaches to housing assistance. Jones (1972), for example, advocated a demand rather than supply-side approach to housing assistance. while the Commonwealth Commission of Inquiry into Poverty (Henderson 1975) 1975 argued for greater targeting of public housing allocations to the poorest citizens. The Australian government initiated a Housing Allowance Voucher Experiment in the late-1970s but abandoned the program without completing it (Department of Environment Housing and Community Development 1976). While the Commonwealth made a number of attempts to transform the subsidy delivery and housing supply arrangements for public housing these have largely been unsuccessful relative to basic budget cutting.

\section{Subsidy shifts}

As the policy imperatives for public housing funding began to change in the late-1970s and early-1980s the state re-examined how subsidies were delivered to public tenants. A particular perception was that the respective roles of the Commonwealth and the States in the provision of housing assistance should be clarified and reorganised via a model that implicitly involved a neoliberal purchaser-provider Commonwealth-State split. A reorganisation was proposed that would give the Commonwealth responsibility for housing affordability, while the States would be responsible for with housing supply (Ministry of Housing 1984b). Such an arrangement would involve the States ensuring a supply of public housing rented at nominal market rents with the Commonwealth providing sufficient rental rebate to ensure an agreed income affordability ratio. This arrangement was viewed as providing greater transparency than the historical matched grants system. Victoria advocated such a shift in the financial and administrative arrangements for public housing during the negotiations for the 1987 CSHA (Ministry of Housing 1986). In 1989, a review of housing assistance retained the existing arrangement although it altered some of the specific Commonwealth-State financial details.

By the mid-1990s, no substantive changes to the governmental means by which housing assistance was provided in Australia had occurred. However, by now the 
Federal state was seeking to clarify the arrangements for public housing to institute a single entitlement to housing assistance. A detailed outline of such an arrangement was never released. But because such a shift would require the assent of the States, the annual Council of Australian Governments (COAG) meeting between the Commonwealth and the States became the venue for this discussion. In 1995, COAG issued a communiqué which articulated the separation of subsidy assistance and housing supply. COAG sought to:

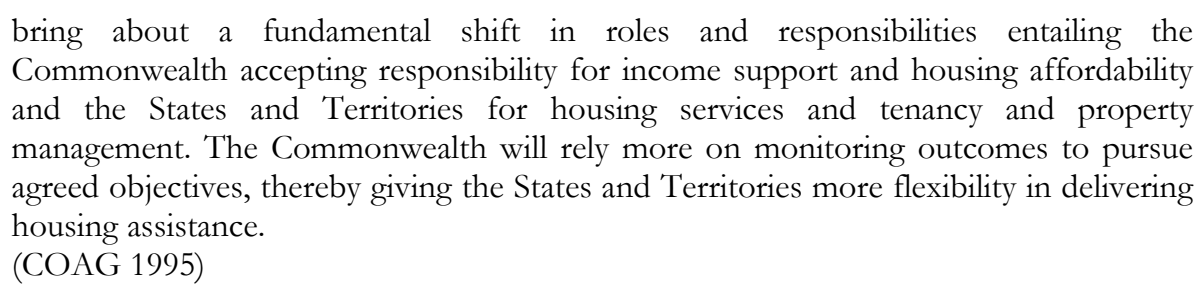
Commonwealth accepting responsibility for income support and housing affordability and the States and Territories for housing services and tenancy and property management. The Commonwealth will rely more on monitoring outcomes to pursue agreed objectives, thereby giving the States and Territories more flexibility in delivering housing assistance.

(COAG 1995)

While the reference to 'flexibility' indicated some of the neoliberal governmentality of housing assistance there was relatively little detail provided. An implementation program began in during 1995 but Labor lost the 1996 Federal election and an incoming conservative Liberal-National coalition government abandoned the proposed reconfigurations in favour of major cuts to the CSHA budget. The Federal government cut $\$ 200$ million from the CSHA during 1997-1998, equating to a $\$ 50$ million cut to Victoria's share (Henderson 1997b). This CSHA also required the States to institute changes to their allocation and rent setting procedures to target public housing to high need groups and to set public housing rents at the same income proportions as applied with the Rent Assistance demand subsidy operated via the Federal government income support system.

Victoria responded by instituting a targeted allocation system utilising a 'segmented waiting list' that prioritised public housing applicants in terms of the assessed degree of social need they suffered (Henderson 1997a, p.3). Subsequently only individuals or households with multiple and complex social and housing needs would be allocated to public housing in Victoria. This exemplifies the Australian mode of neoliberal governmentality in housing assistance; reduced expenditure is combined with increasing state scrutiny of the personal circumstances of the subjects of housing policy. Victoria also responded to the Federal cuts by increasing public housing rents from 20 per cent of income to 25 per cent for new tenants and 23 per cent for existing tenants (Office of Housing 1998). The late-1990s CSHA cuts led the Victorian government contemplated the privatisation of public housing, but dropped this scheme on the advice of its housing officials. Since 1999 there have been few substantial changes to public housing policy in Victoria.

Since the mid-1990s under the conservative Federal rule, supply assistance for public housing has undergone an overall, albeit uneven, decline. By comparison, demand subsidies which rely on recipients individual consumption decisions within the private rental market have become dominant (Figure 2). While housing demand assistance has been used in Australia since the late-1950s (Australian Housing and Urban Research Institute 2001), it is only since the late-1980s (Social Security Review 1987) that this assistance mode has achieved prominence in the Australian housing assistance mix. As has been the case in other jurisdictions, the growing importance of demand subsidisation in Australia marks the incremental shift towards a neoliberal mode of government of housing from a hierarchical and direct mode of assistance provision to a modulated control-oriented mode of provision.

This increase in the importance of Rent Assistance as a mode of housing subsidy delivery has been gradual and has gone largely unnoticed by the broader Australian polity 
except for a few housing researchers and advocates (for example Hulse 2002). However the rise in demand subsidisation as the dominant method of providing housing assistance signifies the encroachment of neoliberalism into Australian housing policy, however incremental.

The Australian case differs from the UK, Netherlands or New Zealand cases as the Australian state has never made a single and comprehensive statement regarding the appropriate disposition of housing subjects or the arrangements for housing assistance. The shift to a neoliberal housing governmentality was announced in these other jurisdictions via specific documents that articulate in detail the re-imagined housing order (Luxton 1991; DETR 2000; MHSPE 2001). In the Australian case, the fragmented and uneven political path to instituting an neoliberal housing governmentality has mean no single document describes in broad spread the re-imagining of housing assistance. The encroachment of neoliberalism in Australian housing policy is apparent in various CSHA agreements and in the various statements produced by the States' housing agencies over time. Australian 'statementality' is thus less overt than in the other cases, but in terms of empirical practice appears remarkably similar.

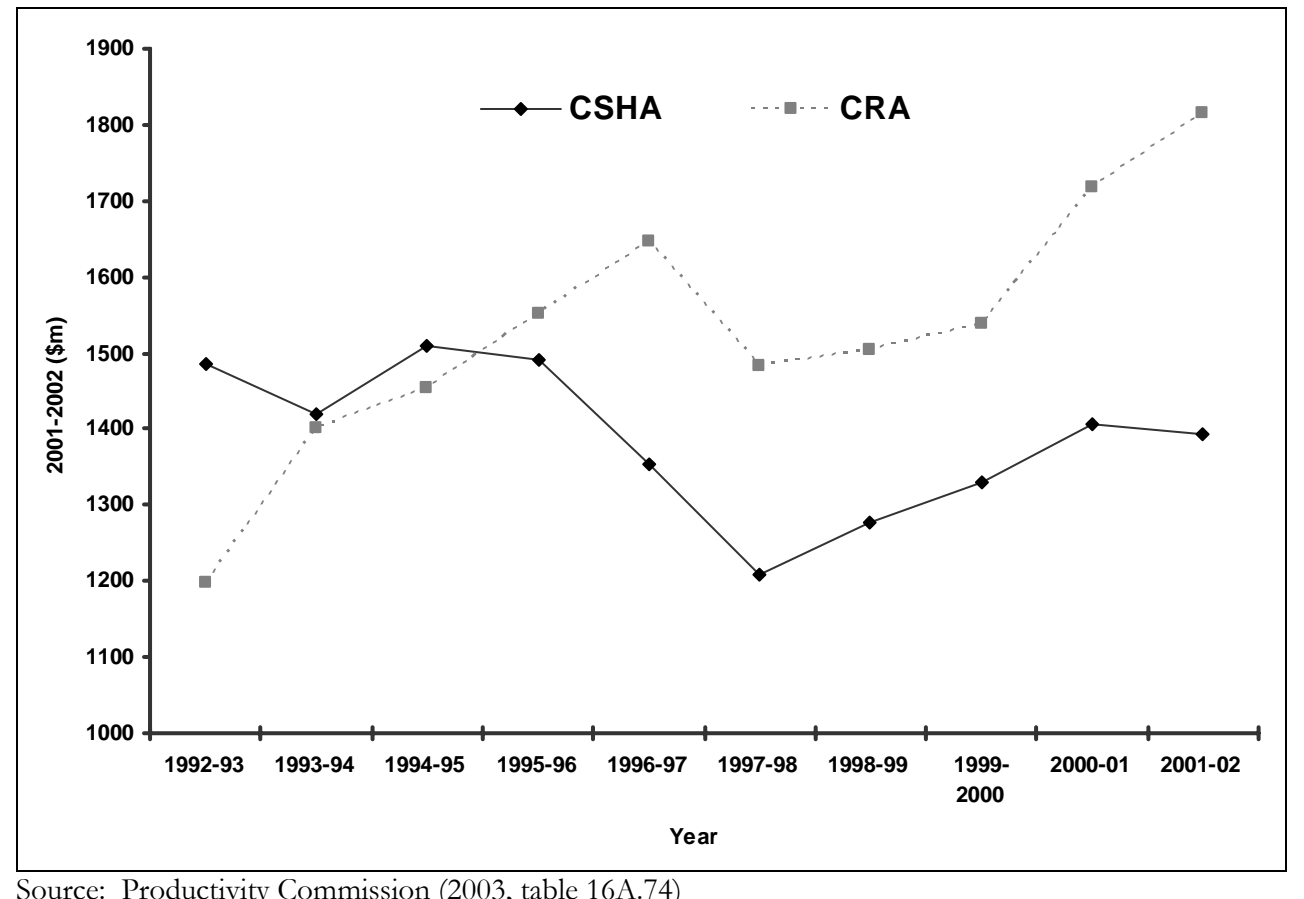

Source: Productivity Commission (2003, table 16A.74)

Figure 2: Commonwealth government housing assistance expenditure on the CHSA and Commonwealth Rent Assistance, 1992-2002, in 2001/2002 dollars .

\section{Conclusions: Housing, neoliberalism and government}

The four case studies presented above have examined how neoliberal imaginations of housing assistance have emerged and have been articulated in the housing policies of four developed nations. In each case the indicators of neoliberal governmentality are apparent. In each case the state remains a dominant force in the production of reimagined housing policy and in the specification of the subjectivities and objects that the state perceives and manipulates in the achievement of governmental objectives. While the adoption of neoliberal concepts and practices in housing is temporally and practically uneven across the four case studies, there remains an abiding and powerful 
'statementality' that acts to articulate and determine the specific housing assistance practices. Understanding this statementality assists to comprehend the perceived 'roll back' and subsequent 'roll out' of the state not in terms of practices of provision, but in terms of practices of conceptualisation and imagination. From such a perspective we can see that the state remains a strong discursive force in housing matters even if it's modes of social and economic intervention may have altered.

The changes in housing assistance appear to reflect a general shift towards neoliberal housing assistance in three critical ways. First the individual rational consumer has been placed at the centre of housing policy. This marks a shift away from a previous unitary subjectivity of generalised poverty. The individual is now perceived as possessing a multivalent set of preferences that guide individual choice of housing. Second, the case studies display an increasing use of housing allowances in the provision of housing assistance. Rather than relying on bureaucratic methods of assistance delivery housing subsidies are increasingly provided through cash transfers, the expenditure of which is left to the individual to determine. Finally, the state retains a strong role under neoliberal housing policy, but rather than intervening directly in housing governmental techniques now emphasise the constitution of rational housing consumers and the modulation of demand and preferences through adjustments to the subsidy and institutional frameworks that support and maintain this individual subjectivity.

Rhe state remains central to the housing system in two ways. First the state retains its dominant historical capacity to constitute, through discursive practices, the order of housing objects and subjects. In each of the four case studies, the state has made definite assertions concerning: the socio-psychological complexion of housing assistance recipients; the institutional frameworks that will govern the provision of housing assistance; and the nature of state action in housing. These are set out in the respective state documents that announced the new regimes (Luxton 1991; DETR 2000; MHSPE 2001). While statementality in housing is less pronounced in the Australian case the legitimate authority to assert and define the imagined order of housing remains that of the state. While the actions of the state may have altered under neoliberalism, this statementality remains.

Second government retains the capacity to effect the imagined order of housing through the institution of empirical practices of housing assistance and is the entity that is able through housing assistance practices to make 'real' and apparent the abstract objects and subjects of housing discourse. The specific empirical practices of housing assistance may have altered in recent decades but their governmental essence continues. Many commentators have viewed the state as having 'rolled back' while some now perceive a 'roll out' (Peck and Tickell 2002). The state remains as discursively pervasive as previously, even if the particular discourse of housing that the state enunciates may have altered, and with it so too have the empirical practices of housing policy.

These observations suggest two implications for housing policy. First, in the absence of threats to its legitimacy - these seem few despite the apparent shrinkage of neoliberalism - the state will remain the primary discursive site through which the objects and subjects of housing policy are conceived, articulated and apprehended. It is conceivable that some other force may articulate a new order of housing assistance that the state adopts, but for this to occur the state would have to adopt this new order as its own in which case the notion of 'statementality' would continue to apply.

Second, the imperative remains for housing scholars to both critically interrogate the objects and subjects articulated by the state as to their basis in social, economic and cultural practice. In doing so we must also comprehend that this injunction applies equally to those statements in which the state articulates its negative disengagement from direct government as much as it expresses its positive engagement with the government 
of housing. As critical scholars we must continue to assess the role of the state in imagining the 'roll' of the state.

\section{References}

Alford, J. and D. O'Neill Eds. (1994). The Contract State: public management and the Kennett government. Geelong, Victoria, Centre for Applied Social Research, Deakin University.

Althusser, L. (1971). Lenin and Philosophy and other essays. New York and London, Monthly Review Press.

Australian Housing and Urban Research Institute (2001). Australian Housing Policy Project: Facts Sheet 4 - A brief history of government involvement. Melbourne, Australian Housing and Urban Research Institute.

Ball, M. (1983). Housing and Economic Power: The political economy of owner occupation. London and New York, Methuen.

Blanc, M. (2004). "The changing role of the state in French housing policies: A roll-out without roll-back." European Journal of Housing Policy; 4 (3): 283-302.

Boelhower, P. (2002). "Trends in Dutch Housing Policy and the Shifting Position of the Social Rented Sector." Urban Studies; 39 (2): 218-235.

Boston, J., J. Martin, J. Pallot and P. Walsh (1996). Public Management: The New Zealand Model. Auckland, Oxford University Press.

Bourdieu, P. (1998). "The Essence of Neoliberalism." Le Monde Diplomatique (December).

Bourdieu, P. and L. Wacquant (2001). "NeoLiberalSpeak: Notes on the new planetary vulgate." Radical Philosophy (105, January/February): 2-5.

Burchell, G. (1993). "Liberal government and techniques of the self." Economy and Society; 22 (3): 267-282.

Burke, T., L. Hancock and P. Newton (1984). A roof over their heads: Housing issues and families in Australia. Melbourne, Institute of Family Studies.

Council of Australian Governments (COAG) (1995). Council of Australian Governments Communique. Canberra, COAG.

De Decker, P. (2004). "Dismantling or Pragmatic Adaptation? On the restyling of welfare and housing policies in Belgium." European Journal of Housing Policy; 4 (3): 261-281.

Dean, M. (1995). "Governing the unemployed self in an active society." Economy and Society; 24 (4): 559-583.

Deleuze, G. (1988). Foucault. Minneapolis, University of Minnesota Press.

Department of Environment Housing and Community Development (1976). The Australian Housing Allowance Voucher Experiment. Canberra, Commonwealth Department of Environment Housing and Community Development.

Department of Environment Transport and the Regions (DETR) (2000). Quality and Choice: A decent home for all; Housing Green Paper. London, UK Government.

Dieleman, F. (1999). "The Impact of Housing Policy Changes on Housing Associations: Experiences in the Netherlands." Housing Studies; 14 (2): 251-259.

Ditch, J., A. Lewis and S. Wilcox (2001). Social Housing, Tenure and Housing Allowance: An international comparison. York, University of York and Department of Work and Pensions.

Doherty, J. (2004). "European Housing Policies: Bringing the State Back In?" European Journal of Housing Policy; 4 (3): 253-560.

Flint, J. (2002). "Social Housing Agencies and the Government of Anti-social Behaviour." Housing Studies; 17 (4): 619-637.

Flint, J. (2004). "Reconfiguring Agency and Responsibility in the Governance of Social Housing in Scotland." Urban Studies; 41 (1): 151-172.

Foucault, M. (1979). "On Governmentality." Ideology and Consciousness; 6.

Friedman, M. and R. Friedman (1981). Free To Choose. Ringwood, Victoria, Penguin Books.

Graham, S. and S. Marvin (2001). Splintering Urbanism: Networked infrastructures, technological mobiities and the urban condition. London and New York, Routledge.

Harloe, M. (1995). The People's Home: Social Rented Housing in Europe and America. Oxford, U.K and Cambridge, USA, Blackwell.

Hayek, F. (1948). Individualism and Economic Order. Chicago, University of Chicago.

Henderson, A. (1997a). Media Release: Victoria Welcomes Federal Government Shift on Public Housing. Minister of Housing, Victorian Government. 13 May.

Henderson, A. (1997b). Victoria welcomes Federal Government Shift on Public Housing. Minister of Housing. 13 May.

Henderson, R. (1975). Commission of Inquiry into Poverty, First Main Report: Volume 1. Canberra, Australian Government Publishing Service. 
Hindess, B. (1993). "Liberalism, socialism and democracy: variations on a governmental theme." Economy and Society; 22 (3): 300-313.

Hoekstra, J. (2003). "Housing and the Welfare State in the Netherlands: an Application of EspingAndersen's Typology." Housing Theory and Society; 20 (20): 58-71.

Housing Corporation of New Zealand (1984). Report of the Housing Corporation of New Zealand for the period ended 31 March, 1984. Wellington, Housing Corporation of New Zealand.

Housing Corporation of New Zealand (1989). Report of the Housing Corporation of New Zealand for the year ended 31 March, 1989. Wellington, Housing Corporation of New Zealand.

Hulse, K. (2002). Demand Subsidies for Private Renters: A comparative review. Melbourne, Australian Housing and Urban Research Institute.

Jensen, J. (1994). "A Conceptual Framework for Monitoring and Assessing Government Policy on Housing Assistance: Some preliminary thoughts from a welfare perspective". Housing Research Conference; 7-8 May, Wellington, Ministry of Housing.

Jessop, B. (1982). The Capitalist State: Marxist Theories and Methods. Oxford, Martin Robertson.

Jones, M. A. (1972). Housing and Poverty in Australia. Carlton, Melbourne University Press.

Kelsey, J. (1993). Rolling back the State: privatisation of power in Aotearoa. Auckland, Bridget Williams Books.

Kelsey, J. (1995). Economic Fundamentalism. London UK and East Haven, Conn., Pluto Press.

Kemeny, J. (1995). From Public Housing to the Social Market: Rental policy strategies in comparative perspective. London and New York, Routledge.

Kemp, P. (1997). A Comparative Study of Housing Allowances. London, Department of Social Security.

King, P. (2003). A Social Philosophy of Housing. Aldershot, Hampshire, Ashgate Publishing Ltd.

Luxton, J. (1991). Housing and Accommodation: Accommodation Assistance. Wellington, New Zealand Government.

Marsh, A. (2004). "The Inexorable Rise of the Rational Consumer? The Blair Government and the Reshaping of Social Housing." European Journal of Housing Policy; 4 (2): 185-207.

McDermott, M. (2004). "Housing Associations, the Creation of Communities and Power Relations." Housing Studies; 19 (6): 855-874.

McGuirk, P. (2003). "Producing the Capacity to Govern in Global Sydney: A multiscaled account." Journal of Urban Affairs; 25 (2): 201-233.

Mill, J. S. (1972). Utilitarianism, On Liberty and Consideration on Representative Government. London, J.M. Dent and Sons.

Ministry of Housing (1984a). Annual Report of Director of Housing, Victoria, 1983-1984. Melbourne, Ministry of Housing.

Ministry of Housing (1984b). Submission from Victoria on the Renegotiation of the Commonwealth/State Housing Agreement. Melbourne, Ministry of Housing.

Ministry of Housing (1986). Commonwealth-State Housing Agreement First Triennial Review 1984-85 to 1986-87, Submission by Victoria. Melbourne, Ministry of Housing.

Ministry of Housing Spatial Planning and the Environment (MHSPE) (2001). What People Want Where People Live: Housing in the 21st Century. The Hague, Netherlands Government.

New Zealand Treasury (1987). Government Management: Brief to the Incoming Government 1987, Volume I. Wellington, New Zealand Treasury.

Nozick, R. (1974). Anarchy, state and utopia. Oxford, Blackwell.

Office of Housing (1998). Summary of Housing Assistance Programs, 1997-98. Melbourne, Department of Human Services.

Office of National Statistics (2004). Living in Britain National Survey 2002. London, UK Government.

Oxley, M. (1987). "The aims and effects of housing allowances in Western Europe", in Housing Markets and Policies under Fiscal Austerity. Edited by W. van Vliet; London, Greenwood Press.

Peck, J. and A. Tickell (2002). "Neoliberalizing Space." Antipode; 34 (3): 380-404.

Persson, D. (1989). National Housing Policy Review: Final Report. Canberra, Department of Community Services and Health.

Poulantzas, N. (1973). Political Power and Social Classes. London, Verso.

Priemus, H. (1996). "Recent Changes in the Social Rented Sector in the Netherlands." Urban Studies; 33 (10): 1891-1908.

Priemus, H. and P. Kemp (2004). "The Present and Future of Income-related Housing Support: Debates in Britain and the Netherlands." Housing Studies; 19 (4): 653-668.

Productivity Commission (2003). Report on Government Services: Attachment. Canberra, Productivity Commission.

Pusey, M. (1991). Economic Rationalism in Canberra: A nation-building state changes its mind. Melbourne, Cambridge University Press.

Rose, N. (1996). "Governing enterprising individuals", in Inventing our Selves: Psychology, power and personhood. Edited by; Cambridge, UK, Cambridge University Press: 1.

Self, P. (2000). Rolling back the market : economic dogma and political choice. Basingstoke, UK., Macmillan. 
Smith, A. (1970). The Wealth of Nations. London/New York, Dent/Dutton.

Social Security Review (1987). Assisting Private Renters: Papers from a workshop. Background Discussion Paper no.18. Canberra, Department of Social Security.

Stephens, M., N. Burns and L. MacKay (2003). "The Limits of Housing Reform: British Social Rented Housing in a European Context." Urban Studies; 40 (4): 767-789.

Topalev, C. (1979). "Can housing policy be an object of research? A stimulating comparative study of British and French housing policy." International Journal of Urban and Regional Research; 3: 445-.

Walker, B. and A. Marsh (2003). "Setting the Rents of Social Housing: The Impact and Implications of Rent Restructuring in England." Urban Studies; 40 (10): 2023-2047.

Whitehead, C. (1993). "Privatising Housing: An assessment of UK experience." Housing Policy Debate; 4 (1): 101-139.

Woods, R. (2000). "Social Housing: Managing Multiple Pressures", in New Managerialism, New Welfare? Edited by J. Clarke, S. Gewirtz and E. McLaughlin; London, Open University and Sage Publications: $137-151$. 